\title{
Variation of growth rate with tidal level in the gastropod Monodonta labio on a boulder shore*
}

\author{
Yoshitake Takada
}

Amakusa Marine Biological Laboratory, Kyushu University, Amakusa, Kumamoto, 863-25, Japan

\begin{abstract}
Growth of Monodonta labio (Linné) (Gastropoda: Trochidae) was investigated bimonthly for a period of $1 \mathrm{yr}$ by quadrat sampling and mark-recapture on a moderately exposed boulder shore in Amakusa, South Japan. Linear regression was calculated for shell width at recapture on shell width at release. Growth in the high zone was slower than in the mid and low zones and decreased as shell width increased. Estimated growth curves fit well with the observed growth curves of individual snails. Seasonal growth patterns of juvenile $(\leq 8 \mathrm{~mm})$ snails may be affected by seasonal fluctuation of microalgal abundance. Due to reproduction, growth of large snails decreased in summer. Tidal level variation of growth rate caused large variation in growth curves in middle-sized snails (ca $10 \mathrm{~mm}$ shell width), because of their wide range of distribution, which was related to vertical migration on the shore. Simulated growth curves showed that $8 \mathrm{~mm}$ snails in the high zone reached asymptotic size (ca $13 \mathrm{~mm}$ ) 1 yr later than snails in the mid and low zones. In small (ca $6 \mathrm{~mm}$ ) and large (ca $13 \mathrm{~mm}$ ) snails, less variability in observed growth curves was explained due to their limited ranges of distribution. This study demonstrates that variation in growth rate is attributable to size-specific distribution on a shore and indicates how migration expands size variation within a single age group.
\end{abstract}

KEY WORDS: Snail · Growth · Tidal level · Migration · Microalgae

\section{INTRODUCTION}

Growth rates of intertidal grazing gastropods may differ with tide level or microhabitat (Paine 1969, Sutherland 1970, Lewis \& Bowman 1975, Creese 1980, McCormack 1982, Fletcher 1984, Underwood 1984b, Jardine 1985). Important factors affecting the growth rate of intertidal limpets include tidal level, wave action, algal food availability, and intraspecific or interspecific competition (Branch 1981). Food availability (microalgal abundance) has been shown to influence growth rate, density, and competition among grazing gastropods (Branch \& Branch 1980, Underwood $1984 \mathrm{~b})$, and this can vary with season and tide level (Underwood 1984a).

Previous studies have been concerned largely with gastropods that have limited mobility relative to the scale of habitat heterogeneity (Sutherland 1970,

- Contribution No. 386 of the Amakusa Marine Biological Laboratory
Fletcher 1984, Jardine 1985) or have experimentally enclosed subjects within specific tidal levels (Creese 1980, McCormack 1982, Underwood 1984b). Migration between different tidal levels or microhabitats, therefore, could be safely ignored. However, mobile animals such as snails may experience several types of habitats during their life history (Paine 1969, McQuaid 1982). This raises questions of (1) how growth varies between habitats and (2) when or why these snails change their habitats. These questions can be applied to other intertidal and subtidal animals (including crustaceans, echinoderms, and fishes) which migrate or diffuse from one habitat to another. To answer these questions, one must trace marked individuals and periodically record their growth and position on the shore.

Monodonta labio (Linné) is a trochid snail which grazes on epilithic microalgae. Usually, it does not graze on the thallus of macroalgae or on epiphytic microalgae growing on that thallus. In Japan, its vertical distribution extends over the entire intertidal zone (Nakano \& Nagoshi 1984). On several boulder shores 
in Amakusa, Kyusyu region, Takada (1992) showed that the size structure of $M$. labio varied with tidal zone; i.e. large snails (ca $14 \mathrm{~mm}$ shell width) were abundant in the low zone, while small (ca $6 \mathrm{~mm}$ ) and middle-sized (ca $10 \mathrm{~mm}$ ) snails were abundant in the mid and high zones, respectively. This suggests variation in growth rate and/or size-specific vertical migration of the snails on the shore.

In this paper, I describe variation in growth rate of Monodonta labio in 3 tidal zones (high, mid, and low intertidal), evaluated by the mark-recapture technique, and compare estimated and real growth curves. I then discuss the factors affecting variation in growth rate and implications for the life history of $M$. labio.

\section{MATERIAL AND METHODS}

Takenouchi (1985) reported 4 types of shell variation in Monodonta labio. Both type A (black-green with white spots) and type B (yellow with dark red spots) have been observed in Amakusa (Takada 1992), but during the course of this study, most of the snails $(99.4 \%, \mathrm{n}=37381)$ were type A.

Field surveys were carried out on a moderately exposed boulder shore on the east side of Magarizaki spit $\left(32^{\circ} 31^{\prime} \mathrm{N}, 130^{\circ} 02^{\prime} \mathrm{E}\right)$, Amakusa Shimo-shima Island, west Kyushu, Japan. The shore slopes gently (Fig. 1a) and the whole intertidal zone is covered by 1 or 2 layers of boulders. The boulders are generally sta-

(a)

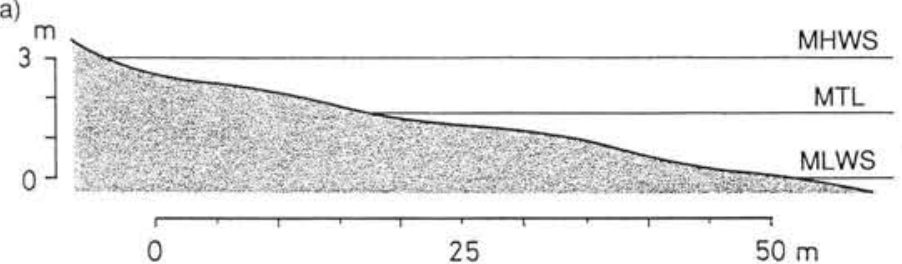

(b)

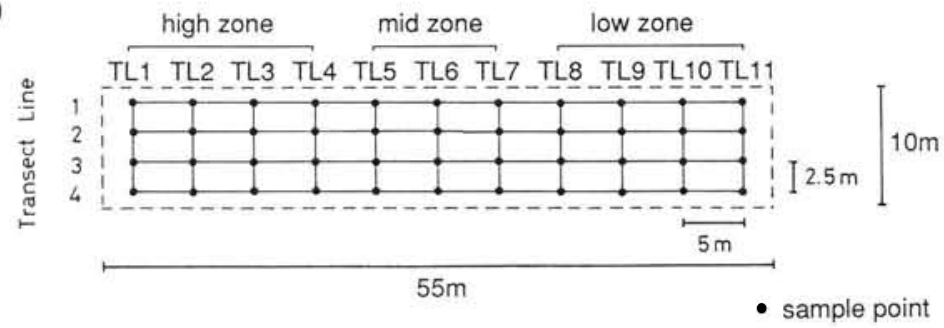

Fig. 1. (a) Profile of the study area. Vertical scale is based on mean low water spring tide (MLWS). (b) Schematic diagram of study area and arrangement of 11 tide levels (TL) and 4 transect lines. TL1 was located $48 \mathrm{~cm}$ below mean high water spring tide (MHWS) and TL11 was located $10 \mathrm{~cm}$ above MLWS. Monthly sampling and mark-recapture experiments were conducted at each intersection point ble except after spring gales or typhoons. The boulders are weathered chert or rhyolite, are almost oval in shape, and are generally without pits or cracks on their surfaces. The mean tidal difference at the study area is $3.0 \mathrm{~m}$ at spring tides. Surface seawater temperature ranged from 12.6 to $26.9^{\circ} \mathrm{C}$. In summer, maximum temperature under boulders at low tide reached about $35^{\circ} \mathrm{C}$. Temperature on the exposed sides of boulders, however, occasionally reached $50^{\circ} \mathrm{C}$. Environmental conditions and community composition around the Amakusa coast have been described in detail by Mori \& Tanaka (1989) and Takada \& Kikuchi (1990, 1991).

Mark-recapture experiment. The study area was a narrow, rectangular area $10 \mathrm{~m}$ along and $55 \mathrm{~m}$ across the shore (Fig. 1b). In this area, 4 transect lines were set at 11 tide levels. Monthly sampling was conducted at the 44 intersection points of this grid (Fig. 1b). The distance between each tide level was $5 \mathrm{~m}$ (about $25 \mathrm{~cm}$ elevation). Because the shore sloped so gently, the Monodonta labio apparently could not change their tidal position during daily foraging excursions (Takada unpubl.).

To investigate the effect of tidal zone on growth variation, one must select individuals which stay in the same tidal zone for a certain period. For snails, marking the outer lip of the shell can be used as an artificial growth line as well as for individual recognition (Hughes 1980, Hughes \& Roberts 1980). Quadrat sampling and multiple mark-recapture experiments were carried out monthly during spring low tides from October 1987 to October 1988 . Four $50 \times 50 \mathrm{~cm}$ quadrats were set around the intersection points. Thus, 16 quadrats at each tide level and a total of 176 quadrats for all tide levels were sampled each month. All Monodonta labio in each quadrat were collected. In the laboratory, shell width (maximum diameter at the aperture) was measured with vernier calipers $( \pm 0.05 \mathrm{~mm})$. Shells were marked with nontoxic paint (Paint Marker, Mitsubishi) and coated with glue (Aron-Alpha, Konishi) at the outer margin of the aperture. Color combinations were changed with sampling month and sample points, and snails collected from the same intersection point in the same month were painted in the same color combination. Within $36 \mathrm{~h}$ after collection, the snails were marked and released at the same points where they were caught. This whole process took 4 to $7 \mathrm{~d}$. Considering the mobility of the snails and interval between samples, bias caused by the previous sampling was believed to be negligible. 
To evaluate the variation in growth rate with tidal height, the study area was divided into 3 zones (Fig. 1b): high zone (TL1 to TL4), mid zone (TL5 to TL7), and low zone (TL8 to TL11). Snails recaptured from the same zone where they had been released 2 mo earlier were considered to have remained in the same zone during this interval. Snails recaptured from different zones were excluded from the analysis of growth rates to eliminate inter-zonal effects. Two months was considered adequate to ensure sufficient growth for accurate measurement and for snails to have remained in the same zone without migration.

Growth rates were described by linear regression equations $(Y=a+b X)$. When the shell width at recapture $(Y, \mathrm{~mm})$ is plotted against the shell width at release $(X, \mathrm{~mm})$, parameters $a$ and $b$ are obtained as the intercept and the slope of the linear regression. Existing growth models are often difficult to apply to snails, not only because increment of shell and size generally do not fit a linear function, but also because the theoretical maximum size is difficult to define (Williamson \& Kendall 1981, Yamaguchi 1975, but see Kaufmann 1981). The purpose of this study was not the application of any particular growth models but description of the growth variation. Factors considered to affect growth variation were size, tidal zone, and individual variation. Differences among the 3 tidal zones were evaluated by heterogeneity tests of regressions. Residual error, which is expected to form a normal distribution around the regression line (Okuno 1986), represents the individual variation of the growth rate. Seasonal changes in increment of shell width were estimated from the parameters of regressions.

Simulated growth curves. Growth curves were constructed from the bimonthly regressions of shell width using a Monte-Carlo computer simulation, so as to represent a cumulative effect of differences in growth rates among the 3 tidal zones. In each group, shell width of a hypothetical snail was calculated 1000 times, and the mean and the standard deviation were obtained. Individual variation of shell width was considered by adding a random deviation which was generated from the residual error around the regression estimated above. Hypothetical snails were considered to be resident in a particular tidal zone. These simulated growth curves were calculated at 2 mo intervals for a $1 \mathrm{yr}$ period from October. Observed growth curves were expected to fall into the range of variation of simulated growth curves.

Microalgal abundance. To measure seasonal and vertical variation in microalgal abundance, rhyolite rock tiles $\left(100 \mathrm{~cm}^{2}\right)$ were placed in the field and the chlorophyll a concentration on the tiles was estimated monthly from December 1990 to December 1991. Concentration of chlorophyll a is thought to represent microalgal abundance on the boulders (MacLulich 1987, Hill \& Hawkins 1991). Five tiles each were placed in the 3 tidal zones (high, mid, and low). To avoid overturning and inundation by sand, experimental tiles were fixed on a wooden board by stainless steel screws, then placed at the bottom layer of the boulders. Grazers were allowed access to the experimental tiles to simulate natural conditions. After $6 \mathrm{wk}$, tiles were brought back to the laboratory and chlorophyll concentrations were estimated by extracting chlorophyll with $90 \%$ ethanol for $24 \mathrm{~h}$ by the polyethylene-bag method (Takada 1993).

\section{RESULTS}

Size-frequency histograms in the 3 tidal zones differed from each other in December 1987 (Fig. 2a). Small snails, with a modal shell width of around $5 \mathrm{~mm}$, occurred only in the mid zone (TL6). Middle-sized snails (mode around $10 \mathrm{~mm}$ ) were abundant in the high zone (TL3) and mid zone, but were rare in the low zone (TL10). Most of the large snails (mode around $14 \mathrm{~mm}$ ) occurred in the low zone but some appeared in the high and mid zones. In the low zone, only large snails occurred in both December 1987 and in June 1988 (Fig. 2b). In June, small and large snails were observed in the mid zone, while middle-sized snails were rare. In the high zone, middle-sized snails were abundant but mode size was not clear.
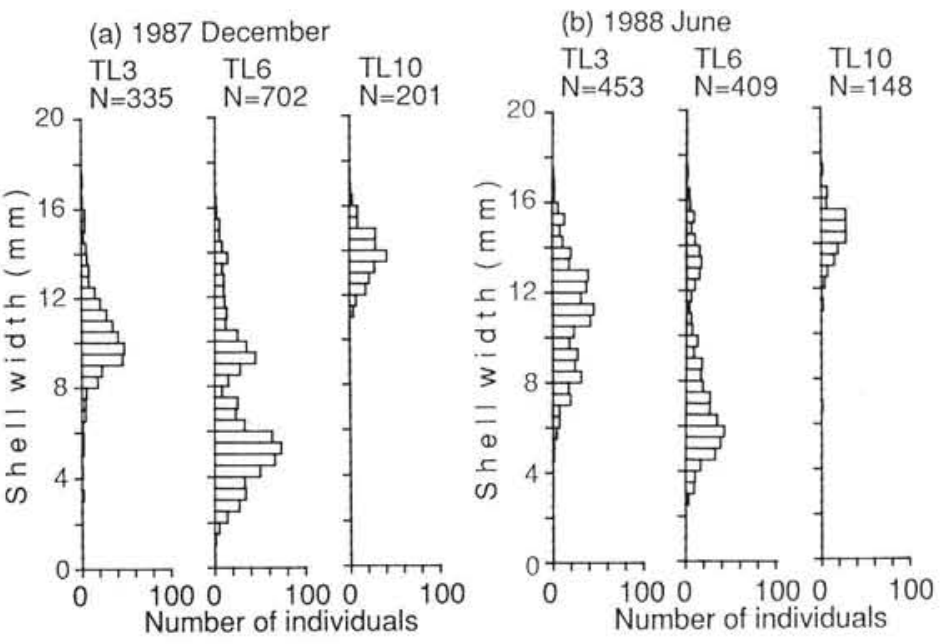

Fig. 2. Monodonta labio. Size histograms at TL3, TL6, and TL10 (representing high, mid, and low zones, respectively) in (a) December 1987 and (b) June 1988. Total numbers of snails (ind. per $4 \mathrm{~m}^{2}$ ) are listed at the top of each histogram 


\section{Individual growth}

A growth curve of each recaptured snail was constructed by plotting the shell width data at successive capture events. Three groups of snails were selected, representing small, middle and large snails. Snails were captured in December when their shell widths ranged between 5.5 and $6.0 \mathrm{~mm}, 9.5$ and $10.0 \mathrm{~mm}$, and 13.5 and $14.0 \mathrm{~mm}$, respectively. Variation in growth curves within the same size group was smaller in small snails than in middle-sized snails (Fig. 3). Some middle-sized snails showed little growth during $5 \mathrm{mo}$, while others grew to a large size (ca $14 \mathrm{~mm}$ ). Small snails, however, grew to about $8 \mathrm{~mm}$ within a period of 6 mo. Large snails grew slowly, and variation within the same group was less than that of middle-sized snails.

\section{Estimation of growth parameters}

The number of snails recaptured after 2 mo ranged from 7 to 37 (Table 1). Some snails ( $\mathrm{n}=109,17.5 \%$ ) migrated vertically during the 2 mo period and were recaptured from other tidal zones; these snails were subsequently excluded from the analysis. All the

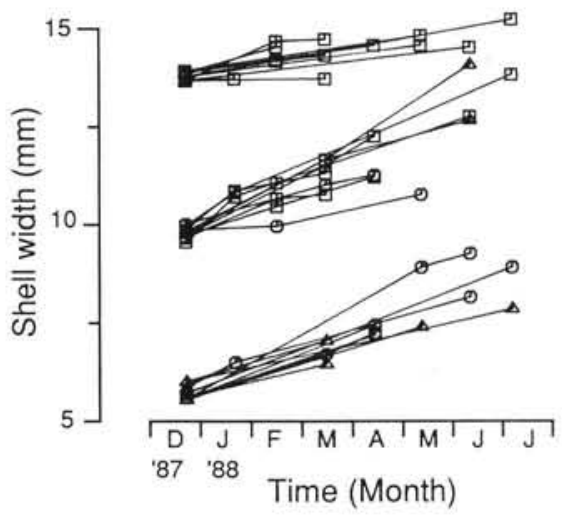

Fig. 3. Monodonta labio. Growth curves of individual snails; size range 5.5 to $6 \mathrm{~mm}, 9.5$ to $10.0 \mathrm{~mm}$ and 13.5 to $14 \mathrm{~mm}$ in January 1988. Symbols represent recaptured tidal zone:

(o) high zone, ( $\Delta$ ) mid zone, and (ㅁ) low zone

regressions of shell width at recapture on initial shell width were significant (ANOVA for simple regression, $\mathrm{p}<0.001$ ). In all months, intercepts and/or slopes of regressions for the 3 tidal zones were significantly different $(\mathrm{p}<0.05$, heterogeneity test for linear regressions; Table 1). Most of the slopes (b) were less than 1 , suggesting that growth rate decreased with an increase in shell width.

Table 1. Monodonta labio. Parameters of linear regression $(Y=a+b X)$ and coefficient of determination $\left(\mathrm{r}^{2}\right)$, calculated from the shell width at recapture $(Y, \mathrm{~mm})$ against the shell width at release $(X, \mathrm{~mm})$. Maximum and minimum shell widths at release used for the calculation are also listed. $\mathrm{H}$ : high zone, $\mathrm{M}$ : mid zone, $\mathrm{L}$ : low zone. $H$-test means heterogeneity test for regressions among 3 zones

\begin{tabular}{|c|c|c|c|c|c|c|c|c|c|}
\hline \multirow[t]{2}{*}{ Period } & \multirow{2}{*}{$\begin{array}{l}\text { Tidal } \\
\text { zone }\end{array}$} & \multicolumn{2}{|c|}{ No. of snails } & \multirow[t]{2}{*}{$r^{2}$} & \multirow[t]{2}{*}{$a$} & \multirow[t]{2}{*}{$b$} & \multirow{2}{*}{$\begin{array}{c}H \text {-test } \\
\mathrm{p}\end{array}$} & \multicolumn{2}{|c|}{ Size range $(\mathrm{mm})$} \\
\hline & & released & recaptured & & & & & Min & Max \\
\hline \multirow[t]{3}{*}{ Oct-Dec 1987} & $\mathrm{H}$ & 909 & 23 & 0.962 & 1.980 & 0.893 & & 3.50 & 10.85 \\
\hline & M & 1089 & 28 & 0.940 & 1.273 & 1.032 & & 3.40 & 11.25 \\
\hline & $\mathrm{L}$ & 555 & 22 & 0.935 & 3.699 & 0.785 & $<0.025$ & 8.20 & 14.85 \\
\hline \multirow[t]{3}{*}{ Dec 1987 - Feb 1988} & $\mathrm{H}$ & 1010 & 26 & 0.936 & 1.724 & 0.905 & & 7.05 & 12.35 \\
\hline & M & 1623 & 19 & 0.979 & 0.520 & 1.077 & & 2.40 & 10.55 \\
\hline & $\mathrm{L}$ & 902 & 37 & 0.984 & 2.776 & 0.836 & $<0.05$ & 4.80 & 15.65 \\
\hline \multirow[t]{3}{*}{ Feb-Apr 1988} & $\mathrm{H}$ & 1202 & 20 & 0.985 & 1.619 & 0.898 & & 3.95 & 12.50 \\
\hline & M & 1248 & 27 & 0.985 & 1.241 & 0.973 & & 2.35 & 12.65 \\
\hline & $\mathrm{L}$ & 1060 & 37 & 0.964 & 1.969 & 0.898 & $<0.01$ & 5.60 & 15.60 \\
\hline \multirow[t]{3}{*}{ Apr-Jun 1988} & $\mathrm{H}$ & 1273 & 33 & 0.962 & 2.408 & 0.809 & & 4.90 & 11.85 \\
\hline & M & 1145 & 24 & 0.959 & 1.471 & 0.971 & & 2.25 & 12.00 \\
\hline & $\mathrm{L}$ & 809 & 35 & 0.988 & 2.184 & 0.879 & $<0.05$ & 3.15 & 16.95 \\
\hline \multirow[t]{3}{*}{ Jun-Aug 1988} & $\mathrm{H}$ & 1685 & 32 & 0.968 & 2.216 & 0.817 & & 6.10 & 12.55 \\
\hline & M & 1467 & 13 & 0.926 & 2.966 & 0.774 & & 3.00 & 8.20 \\
\hline & $\mathrm{L}$ & 884 & 16 & 0.982 & 4.001 & 0.729 & $<0.001$ & 4.40 & 15.25 \\
\hline \multirow[t]{3}{*}{ Aug-Oct 1988} & $\mathrm{H}$ & 1569 & 7 & 0.989 & 1.578 & 0.888 & & 7.10 & 15.55 \\
\hline & M & 556 & 8 & 0.994 & 3.544 & 0.731 & & 5.10 & 13.00 \\
\hline & $\mathrm{L}$ & 755 & 17 & 0.993 & 3.883 & 0.725 & $<0.001$ & 5.15 & 15.35 \\
\hline
\end{tabular}


Fig. 4. Monodonta labio. Bimonthly increment of shell width of standard snails estimated from parameters of linear regressions listed in Table 1. Standard sizes were (a) $5 \mathrm{~mm}$, (b) $8 \mathrm{~mm}$, (c) $11 \mathrm{~mm}$, and (d) $14 \mathrm{~mm}$. Open symbols show that the standard size was out of the size range used for the estimation of growth parameters
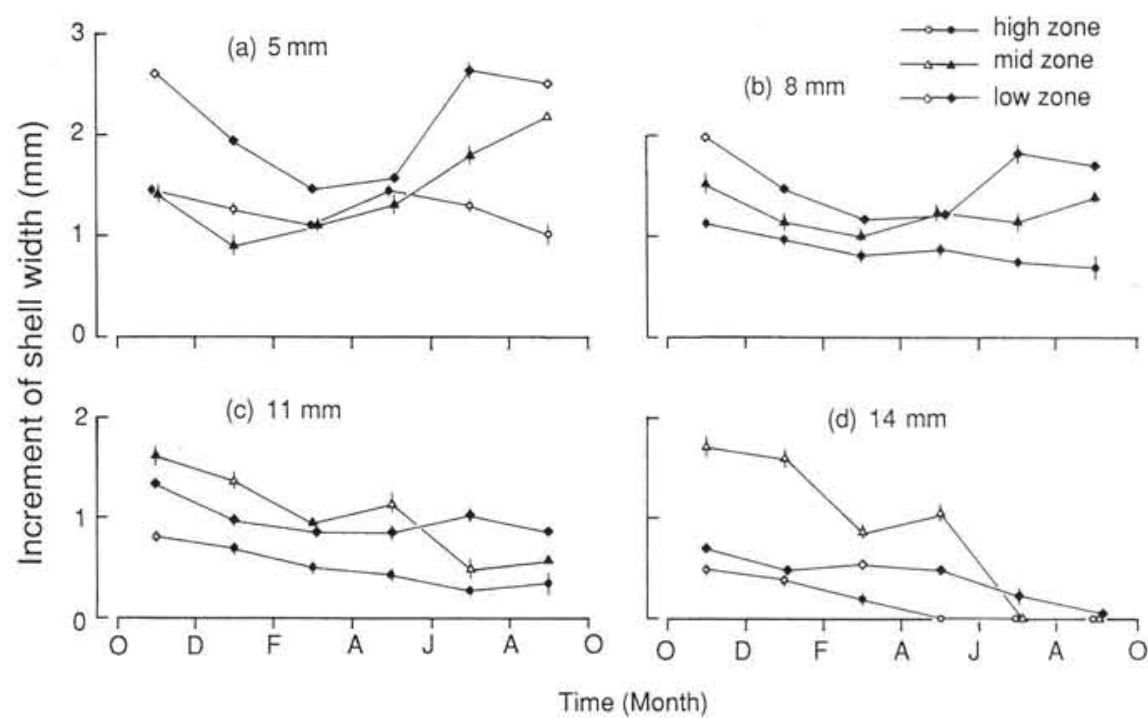

Seasonal changes in the increment of shell width were estimated from the parameters of regressions (Fig. 4). Standard sizes of 5, 8, 11, and $14 \mathrm{~mm}$ were chosen for the calculation. These sizes were representative because $5 \mathrm{~mm}$ and $14 \mathrm{~mm}$ were modal sizes of small and large snails, respectively, in December (Fig. 2) and the minimum maturation size was $8 \mathrm{~mm}$ (Takada pers. obs.). Then $11 \mathrm{~mm}$ was chosen to keep a constant interval. When the shell width fell out of the size range (see Table 1) used for parameter estimation, accuracy of the estimation became less reliable; nevertheless, the figures show consistent patterns. Generally, bimonthly increments of shell width were lower in the high zone than those in the mid and low zones. Tidal zone differences in increment of the $5 \mathrm{~mm}$ and the $8 \mathrm{~mm}$ snails were greatest in the summer but smaller in the spring, while the differences in $11 \mathrm{~mm}$ snails were almost constant during the whole year. Patterns of seasonal fluctuations of shell growth were different in different size classes. In summer, the $14 \mathrm{~mm}$ snails stopped growing, while the $5 \mathrm{~mm}$ and the $8 \mathrm{~mm}$ snails in high and mid zones grew faster in summer than in winter.

\section{Simulated growth curves}

Six growth curves were estimated to evaluate the variations with size and tidal zone. Initial sizes and their respective tidal zones were selected according to the modal sizes in December (Fig. 2): $4 \mathrm{~mm}$ in the mid zone, $8 \mathrm{~mm}$ in the high, mid, and low zones, $11 \mathrm{~mm}$ in the high and low zones. A growth curve of $11 \mathrm{~mm}$ snails in the mid zone was not calculated because the size range used for the estimation did not include such large sizes. Differences in growth rate among the 3 tidal zones caused large variation in growth curves (Fig. 5). Variations of growth curves among the tidal zones were larger in $8 \mathrm{~mm}$ snails than in $11 \mathrm{~mm}$ snails. Middle-sized snails $(8 \mathrm{~mm})$ reached a size of about $13 \mathrm{~mm}$ after $1 \mathrm{yr}$ in the mid and low zones, which is comparable to the growth of $11 \mathrm{~mm}$ snails in the high zone. If $8 \mathrm{~mm}$ snails stayed in the high zone, they reached $11.6 \mathrm{~mm}$ after $1 \mathrm{yr}$ and spent $2 \mathrm{yr}$ to reach about $13 \mathrm{~mm}$. The $4 \mathrm{~mm}$ snails grew steadily in both the mid and low zones and reached $10 \mathrm{~mm}$ by the next October.

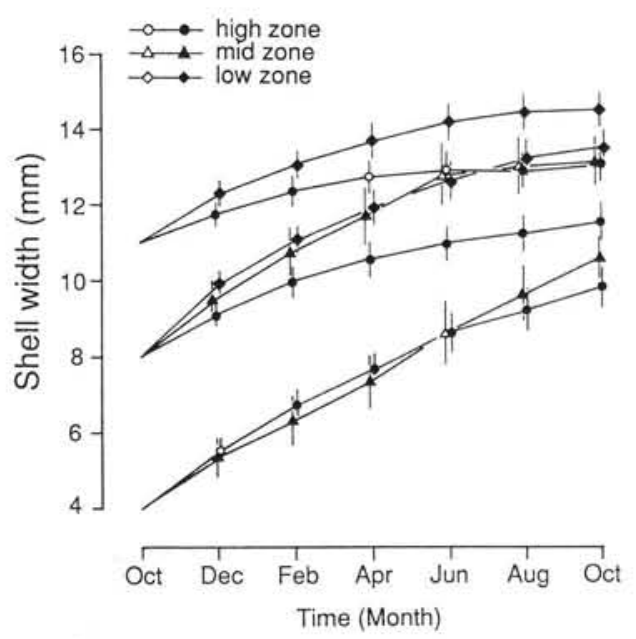

Fig. 5. Monodonta labio. Simulated growth curves of the hypothetical snails estimated by using the growth parameters ( $a$ and $b$ in Table 1). Vertical migration between the tidal zones was not considered for the estimation. Open symbols show that the mean sizes are out of the range of the estimation of the growth parameters. Vertical bars are SD $(n=1000)$ 
Table 2. Two-way ANOVA for effects of months and tidal zones on chlorophyll a concentration (log-transformed) on the experimental rock tiles

\begin{tabular}{|lrccc|}
\hline Source & df & MS & $F$ & p \\
\hline Month & 12 & 0.622 & 57.8 & $<0.001$ \\
Tidal zone & 2 & 0.577 & 53.7 & $<0.001$ \\
Interaction & 24 & 0.161 & 15.0 & $<0.001$ \\
Error & 147 & 0.011 & & \\
\hline
\end{tabular}

\section{Microalgal abundance}

Result of 2-way ANOVA shows that all factors (month, tidal zone, and interaction) were significant (Table 2). Microalgal abundance was high in the low zone and low in the high zone (Fig. 6). Generally, it increased in winter and decreased in summer. Patterns of seasonal fluctuation, however, varied slightly between the different tidal zones. Maximum chlorophyll a concentration $\left(445.7 \mu \mathrm{g}\right.$ per $\left.100 \mathrm{~cm}^{2}\right)$ was observed in the low zone in December 1990. From January to June 1991, the abundances in the low zone and in the mid zone were very similar. On the other hand, from June to August and in December 1991, the abundances in the mid zone and in the high zone were similar to each other.

\section{DISCUSSION}

\section{Growth patterns}

In this study, a linear regression equation was applied to describe the growth of Monodonta labio. In some cases, existing growth equations did not fit the real growth patterns. Hughes (1980), studying growth of Littorina nigrolineata using a mark-recapture technique, applied a simplified von Bertalanffy equation, but arbitrarily extrapolated a curve for smaller sizes as the growth of smaller snails did not fit the linear function. Growth estimation beyond the size range used in the parameter estimation was not attempted in this study. Measurement interval also affects the estimation of growth parameters (Yamaguchi 1975), but in this study, the time span of 2 mo represented the observed growth rate very well.

In Shima Peninsula, in central Japan, Nakano \& Nagoshi $(1981,1984)$ studied the growth and longevity of Monodonta labio by cohort analysis and distinguishing age groups. Generally the results of the present study agree with their findings; snails grow well in winter and large snails stop growing in summer. However, juvenile snails $(<11 \mathrm{~mm}$ shell width) grew more and adult snails grew less in Amakusa than in Shima Peninsula. This difference affects the maximum size of the snail, i.e. in Shima Peninsula, the maximum size is larger (more than $20 \mathrm{~mm}$ ) than in Amakusa $(17 \mathrm{~mm})$. In Shima Peninsula, newly recruited juveniles appeared in December (about $4 \mathrm{~mm}$ shell width) and grew to $9 \mathrm{~mm}$ by the next December (Nakano \& Nagoshi 1984). In Amakusa, $4 \mathrm{~mm}$ snails grew to $10 \mathrm{~mm}$ during the comparable period. In Hakata Bay, north Kyushu, Sumikawa (1955) reported that $5 \mathrm{~mm}$ snails in December ( 0 age group) grew to $14 \mathrm{~mm}$ by the next December, the fastest growth of the 3 studies, but by the next year, these snails showed little growth and died by summer. These differences may be the results of local differences in environmental factors, such as food, or the mode of data analysis, such as between the mark-

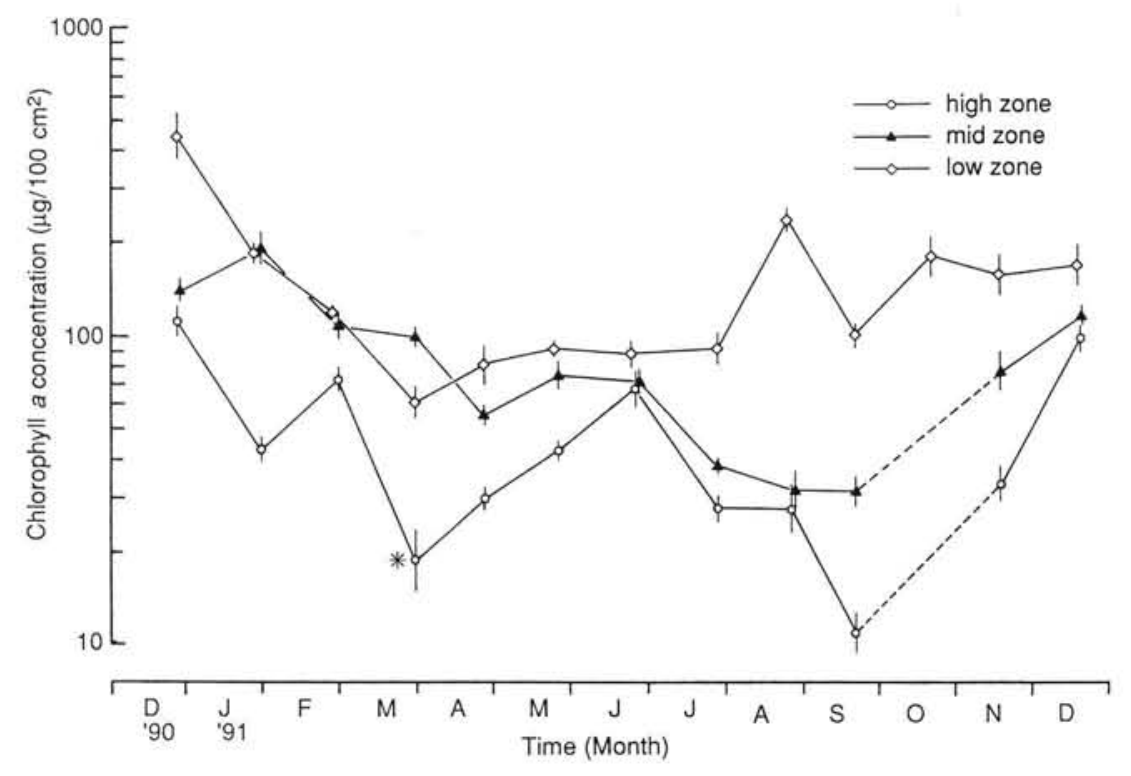

Fig. 6. Monthly change in mean microalgal abundance $\left(100 \mathrm{~cm}^{2} ; \mathrm{n}=5, * \mathrm{n}=4\right)$ with $1 \mathrm{SD}$ observed on the rhyolite rock tiles experimentally placed in the high, mid, and low zones 
recapture technique (present study) and cohort analysis (other studies). In Amakusa, because the mode size in the high zone became obscure in June, cohort analysis was not reliable. Williamson \& Kendall (1981) reported that Monodonta lineata, a European congeneric species, grows well in the summer but stops growing in the winter. This growth season is the inverse of that of M. labio, and could be due to the warmer temperatures in Amakusa.

\section{Causes of growth variation}

Several studies have examined differences in growth rate of gastropods with respect to tidal zone (Paine 1969, Sutherland 1970, Fletcher 1984, Jardine 1985). Growth of intertidal herbivorous gastropods is considered to be related to the microalgal abundance (Branch \& Branch 1980, Creese 1980, Underwood $1984 \mathrm{a}, \mathrm{b}$ ). The abundance of microalgae (the only food for Monodonta labio) varied with season and tidal zones. It was generally higher in the fall and winter, and lower in the spring and summer. Differences among the 3 tidal zones were small in the spring and large in the summer. This agrees very well with the variation of shell growth observed in small (5 and $8 \mathrm{~mm}$ ) snails. Therefore, growth in small M. labio may be affected principally by microalgal abundance.

Growth patterns in larger Monodonta labio, however, are not clearly explained by the abundance of microalgae. In summer, the abundance of microalgae was low in the high zone but was rather high in the low zone, however the growth rate of large $M$. labio was much lower than that of the small snails. The decrease in growth rate of $M$. labio in the summer may be related to the allocation of extra energy for reproduction (Wright \& Hartnoll 1981, Quinn 1988a, b). Earlier studies reported that the reproductive season for $M$. labio was summer (June to September: Sumikawa 1958, 1963; July and August: Kojima 1962) and snails matured at a size of about $7 \mathrm{~mm}$ (Sumikawa 1965) or $11 \mathrm{~mm}$ (Nakano \& Nagoshi 1984). Therefore, the lower growth rate of large snails could be related to summer reproductive activity.

Simulated growth curves showed that growth variation due to the difference of tidal zones would occur both in the large and middle-sized snails. However, wide variations in individual growth curves were observed only in the middle-sized snails. Growth variation in the middle-sized snails was due both to differences in growth rate among tidal zones and wide vertical distribution range. Middle-sized snails occurred both in the high and mid zones (Fig. 2a; Takada 1992), while most of the large snails were confined to the low zones. Therefore, growth variations of large snails were less than those of middle-sized snails. For small snails, both the limited distribution range and the less variable growth rates among tidal zones affect the narrow variation in observed growth curves. Because small snails occurred only in the mid zone, middlesized snails must have migrated upward from the mid zone to the high zone (Takada unpubl.). Therefore, variation in vertical migration behavior caused the wide distribution range and hence the wide variation of growth rate in middle-sized snails. The obscure mode of the size-frequency histogram in the high zone in June (Fig. 2b) was the result of the growth variation.

Early in the paper, I raised 2 questions about mobile snails: (1) how growth varies between habitats, and (2) when or why these snails change their habitats. By using the mark-recapture experiment, I have demonstrated that large growth variation among the tidal zones occurred in middle-sized Monodonta labio. With cohort analysis to describe growth rate, growth variation among the tidal zones was confounded by the vertical migration of snails. To analyze the growth rate of a mobile snail, migration should not be ignored because it expands size variation within a same age group. Mark-recapture experiments will demonstrate detailed size and age structure and habitat utilization of the population.

Acknowledgements. I thank Prof. T. Kikuchi and M. Tanaka for giving me the opportunity to study this subject and for suggesting the research design. K. Nandakumar, G. A. Williams, and S. E. Stancyk kindly revised the manuscript. Thanks are due to K. Mori, K. Takenouchi, and S. Nishihama for valuable discussions during the course of this study. I. Goto and T. Sameshima kindly assisted me in my field work. This study was partly supported by a Grant-in-Aid for Scientific Research (63480007) from the Ministry of Education, Science, and Culture, Japan, and a JSPS Fellowship for Junior Scientist (1182).

\section{LITERATURE CITED}

Branch, G. M. (1981). The ecology of limpets: physical factors, energy flow, and ecological interactions. Oceanogr. mar. Biol. A. Rev. 19: 235-380

Branch, G. M., Branch, M. L. (1980). Competition in Bembicium auratum (Gastropoda) and its effect on microalgal standing stock in mangrove muds. Oecologia 46: 106-114

Creese, R. G. (1980). An analysis of distribution and abundance of populations of the high-shore limpet, Notoacmea petterdi (Tenison-Woods). Oecologia 45: 252-260

Fletcher, W. J. (1984), Intraspecific variation in the population dynamics and growth of the limpet, Cellana tramoserica. Oecologia 63: 110-121

Hill, A. S., Hawkins, S. J. (1991). Seasonal and spatial variation of epilithic microalgal distribution and abundance and its ingestion by Patella vulgata on a moderately exposed rocky shore. J. mar. biol. Ass. U.K. 71: 403-423

Hughes, R. N. (1980). Population dynamics, growth and reproductive rates of Littorina nigrolineata Grey from a moderately sheltered locality in north Wales. J. exp. mar. 
Biol. Ecol, 44: 211-228

Hughes, R. N., Roberts, D. J. (1980). Growth and reproductive rates of Littorina neritoides (L.) in north Wales. J. mar. biol. Ass. U.K. 60: 591-599

Jardine, I. W. (1985). Height on the shore as a factor influencing growth rate and reproduction of the top-shell Gibbula cineraria (L.). In: More, R. G., Seed, R. (eds.) The ecology of rocky coast. Hodder and Stougton, London, p. 117-135

Kaufmann, K. W. (1981). Fitting and using growth curves. Oecologia 49: 293-299

Kojima, K. (1962). On the spawning of a top-shell, Monodonta labio (Linné). Venus 22: 200-203

Lewis, J. R., Bowman, R. S. (1975). Local habitat-induced variations in the population dynamics of Patella vulgata L. J. exp. mar. Biol. Ecol. 17: 165-203

MacLulich, J. H. (1987). Variation in the density and variety of intertidal epilithic microflora. Mar. Ecol. Prog. Ser. 40: 285-293

McCormack, S. M. D. (1982). The maintenance of shore-level size gradients in an intertidal snail (Littorina sitkana). Oecologia 54: 177-183

McQuaid, C. D. (1982). The influence of desiccation and predation on vertical size gradients in populations of the gastropod Oxystele variagata (Anton) on an exposed rocky shore. Oecologia 53: 123-127

Mori, K., Tanaka, M. (1989). Intertidal community structures and environmental conditions of exposed and sheltered rocky shores in Amakusa, Japan. Publ. Amakusa Mar. Biol. Lab. 10: 41-64

Nakano, D., Nagoshi, M. (1981). Age structure and growth in a population of Monodonta labio (Linnaeus) at Shima Peninsula, Japan. Venus 40: 34-40 (in Japanese with English abstract)

Nakano, D., Nagoshi, M. (1984). Growth and death in an intertidal population of Monodonta labio (Linnaeus), (Prosobranchia, Trochidae). Venus 43: 60-71 (in Japanese with English abstract)

Okuno, C. (1986). Handbook of applied statistics. Youkendo, Tokyo (in Japanese)

Paine, R. T. (1969). The Pisaster-Tegula interaction: prey patches, predator food preference, and intertidal community structure. Ecology 50: 950-961

Quinn, G. P. (1988a). Ecology of the intertidal pulmonate limpet Siphonaria diemenensis Quoy et Gaimard. I. Population dynamics and availability of food. J. exp. mar. Biol. Ecol. 117: 115-136

Quinn, G. P. (1988b). Ecology of the intertidal pulmonate limpet Siphonaria diemenensis Quoy et Gaimard. II. Reproductive patterns and energetics. J. exp. mar. Biol. Ecol. 117: 137-156

Sumikawa, S. (1955). Longevity of a gastropod, Monodonta labio (Linné) in Hakata Bay. Science of Human Life,

This article was submitted to the editor
Fukuoka Women's Univ. 3: 75-82 (in Japanese with English abstract)

Sumikawa, S. (1958). On the seasonal changes in gonad of Monodonta labio L., with special reference to ovary. Science of Human Life, Fukuoka Women's Univ, 4: 63-66 (in Japanese with English abstract)

Sumikawa, S. (1963). Comparative physiological and ecological studies on the useful gastropods and lamellibranch. I. Histological studies on the seasonal changes of the gonad. Science of Human Life, Fukuoka Women's Univ. 6: 11-33 (in Japanese with English abstract)

Sumikawa, S. (1965). Hermaphroditism in Monodonta labio L. Science of Human Life, Fukuoka Women's Univ, 6: 217-220 (in Japanese with English abstract)

Sutherland, J. P. (1970). Dynamics of high and low populations of the limpet, Acmaea scabra (Gould). Ecol. Monogr. 40: $169-188$

Takada, Y. (1992). Tide level variation of morph frequency and size structure in Monodonta labio (Gastropoda: trochidae) at several boulder shores in Amakusa. Venus 51: $187-195$

Takada, Y. (1993). Evaluation of methods for chlorophyll estimation of littoral epilithic microalgae. Benthos Res. (Japan) 44: 45-55 (in Japanese with English abstract)

Takada, Y., Kikuchi, T. (1990). Mobile molluscan communities in boulder shores and the comparison with other intertidal habitats in Amakusa. Publ. Amakusa Mar. Biol. Lab., Kyushu Univ. 10: 145-168

Takada, Y., Kikuchi, T. (1991). Seasonal and vertical variations of the boulder shore fauna in Amakusa. Publ. Amakusa Mar. Biol. Lab., Kyushu Univ. 11: 1-17

Takenouchi, K. (1985). An analysis of shell character and distribution of the intertidal trochid, Monodonta labio (Linné) (Gastropoda: Prosobranchia). Venus 44: 110-122 (in Japanese with English abstract)

Underwood, A. J. (1984a). The vertical distribution and seasonal abundance of intertidal microalgae on a rocky shore in New South Wales. J. exp. mar. Biol. Ecol. 78: 199-220

Underwood, A. J. (1984b). Microalgal food and the growth on the intertidal gastropods Nerita atramentosa Reeve and Bembicium nanum (Lamarck) at four heights on a shore. J. exp. mar. Biol. Ecol. 79: 277-291

Williamson, P., Kendall, M. A. (1981). Population age structure and growth of the trochid Monodonta lineata determined from shell rings. J. mar. biol. Ass. U.K. 61: 1011-1026

Wright, J. R., Hartnoll, R. G. (1981). An energy buget for a population of the limpet Patella vulgata. J. mar. biol. Ass. U.K. 61: 627-646

Yamaguchi, M. (1975). Estimating growth parameters from growth rate data: problems with marine sedentary invertebrates. Oecologia 20: 321-332

Manuscript first received: March 21, 1994

Revised version accepted: October 26, 1994 